DOI: 10.15643/libartrus-2015.1.1

\title{
Communicative Space End Intertextual Underlying Cause in B. Shlink's Novel “The Homecoming”
}

\author{
(C) T. A. Sharypina \\ Lobachevsky State University \\ 23 Gagarin Ave., 603950 Nizhny Novgorod, Russia. \\ Email: kafzl@yandex.ru
}

\begin{abstract}
In this work, the peculiarities of the communicative space in the novel of modern German writer Bernard Shlink "The Homecoming" are considered. These peculiarities include literary, historical and sociological context and intertextual sub-bases of the novel containing sense bearing matters relevant for all times and nationalities; dialogic relations, expressed in the strategy of communication of characters of the novel. It is proved that the communicative space is not limited in the novel by antiquity, but rather includes token for German mentality works, motifs and images. The famous Faust's dilemma is being played up in the novel. Revealing in the mythological images models of main psychological types and conflicts connected with the type of the personality, B. Shlink creates in his novel a number of Odysseuses, Penelopes and Telemaches. The Odysseus model manifests itself primarily in two main characters of the novel: Peter and Johann Debauers. However, the father personifies only destructive and immoral, which finally leads to his moral inability, the Odysseus-junior - Peter, who played Telemachus in the beginning of the novel, finds in his wanderings solid moral values. Perceiving the myth as a historical and dialectic process, B. Shlink, like Th. Mann, takes it as a peculiar cipher of the human experience, a model of development of the humanistic values, a prototype of mutual battle between progress and regress, which b. Shlink masterfully describes in a communicative space of his novel.
\end{abstract}

Keywords: the communicative space, post-modernism, intertextuality, dialogue, novel, text, archetypical model, language behavior.

Modern writers are constantly looking for new methods of reconstructions of communication processes [1-8], new principles of organization of dialogic situations and analysis of communicative relations. B. Gasparov defines the communicative space as a "mentally imagined space" or "spiritual environment" that allows to interpret the meaning of the message or statement with a maximum precision [4, p. 69].

Dialogic relations that appear "over" conversations of the characters acquire a special meaning.

Communication strategy is expressed in the characters' language behavior. The choice of strategy is based on their moral values, intellectual outlook and social role [5]. The methodology of this work is based on the historical-literary, typological, comparative, and descriptive methods of the research of literary phenomena.

The communicative space in B. Shlink's novel "The homecoming" ("Die Heimkehr", 2006) is multilayered [8-11]. These are, in the first place, dialogic relations between the writer and his readers: he makes them use their intellectual memory to comprehend the meaning of the plot and rather peculiar communicative relations between the hero of the book Peter Debauer and his father John de Bauer (Johann Debauer). B. Shlink includes into communicative space of his novel ample literary, historical and sociological context that gives an idea of a life in Germany during and after the war. In this communicative space the hero of Shlink's novel is at the same time Telemachus and Odysseus of the post-war generation of children, that try to find out answers for tragic questions arisen by the history 
of German national "quilt of fathers" and also find their own place in this life and realize for themselves that moral values are unshakable. Exactly for this reason this new Telemachus having grown up works in a prestigious publishing house where juridical literature is his specialty and he also works on a doctoral dissertation called "The utility of justice". The idea came to him from his noble grandfather who taught him to be fair from his very childhood and who was representing in this novel eternal moral values. The style of the novel is transparent, serious and heart-felt because some of its realias and details correlate with author's childhood and juvenility spent in Germany. It's very distinctive in "Swiss" episodes of the novel, dedicated to hero's grandparents. A peaceful patriarchal town on the bank of the lake in a German-part of Switzerland becomes an ideological Ithaca for Peter Debauer. B. Shlink does not use poetics of post-modernism epoch connected with numerous intertextuality to be ironic towards his readers (there is no irony in the author's speech - it exists only in "modern Ulysses's" - Johann Debauer's speech). Intertextual sub-bases of the novel allows him to widen communicative space and add to it sense bearing matters relevant for all times and nationalities and to choose from them token for German mentality works, motifs and images. All the power of the communicative space implemented by the author is used by him to prove the thesis on "the utility of justice" that find evidence in all the times and epochs.

Intertextuality $[12,13]$ does not make it difficult to read the novel. The contents of the novel is still revealed completely only to intellectual readers. Thus, grandparents of the hero that have a plain household and useful activities remind not Laertes and Anticlea, but rather modern Philemon and Baucis with an unshowy, but cozy landscape in the background - all with a reference to the second part of Goethe's "Faust" where peaceful life of old people gets in the pseudoprogress'es way. Goethe's characters die on the same day killed as in the antique myth by Mephistopheles, who embodies Faust's grandiose intentions. In the novel 'the Homecoming' grandparents' regular life is disturbed by the technical progress which finally puts an end to their existence.

The communicative space in the novel is not limited by antiquity. Thus, Peter Debauer could be called "modern Faust". The famous Faust's dilemma is played up in the novel. However, the modern Faust do not ask himself what is more important - what is said or what is written; he is rather concerned about their interrelation: words written or said are expressed in the doings and these doings follow the words. Peculiarity of the communicative space and situation consists in the personal relations and conversations of the father and the son, their dialogues meant to solve father's (Johann Debauer's) riddles by his son modern-Faust-Telemachus - that give no result.

The real meaning of father's actions is revealed not in the words said, but in the words written and fixed. Only his literary, publicistic, epistolary, scientific texts ("words") allow the father to follow his life and his deeds.

Post-modernists overemphasize the text as an independent category, rejecting the only possibility to comprehend the truth. The understanding of the "occurrence" as a text makes the process of objective comprehension of the reality and historical process doubtful and, consequently, the definition of the good and the evil, the right and the wrong dissolves in the moral relativism. However, $\mathrm{B}$. Shlink, according to the traditions of realistic narration, unlike his character, does not play with the text $[14,15]$. What is written is a method of a deep psychological portraiture of the characters, indicator of the deception and the truth, the good and the evil, the quilt and the responsibility, first of all, in Johann Debauer (John de Bauer) character, elusive Odysseus and the father of the hero of the book. Johann Debauer has several typical masks in the novel. For example, he is a student, a volunteer trench-fighter Volker Vonlanden, the supporter of one of the Nazi leaders Karl Hanke. He also writes 
letters to Beate Bindinger (one of the Penelopes of the modern Odysseus) and a number of nazi-articles in German war-period newspapers that prove the right of Germany to conduct wars with inferior nationalities according to the ironclad rule - because Germany is stronger.

Another mask of the sophisticated Odysseus is an intelligent Walter Sholler who belonged to Johann Becher's circle. He was in charge of culture department in the newspaper "Night Express" in a post-war East Berlin, where he wrote articles under control of the Soviet Mayor of military administration.

In a number of texts written by the sophisticated and elusive Ulysses, "The novel for pleasure and useful entertainment" is especially important. This novel was a reason for Peter Debauer to begin looking up the truth about his father, family and about himself. The novel which was written with simple materialistic aims, was supposed to be popular among post-war German readers because it is related to the novels about returning from the Siberian captivity soldiers. Such mass literature works were popular because they inspired hope, at least delusive, that there is a successful possibility to escape and come home. Johann Debauer used the details of real living and events from his biography to exploit readers' internal hopes; he reconstructed, ironically playing with them, false reality, a simulator $[16,17]$.

The paradox is that he has never been captured and never gone through those tortures that he described. Nevertheless, he uses the plot of Homer's "the Odyssey"| to enrich his fantasy. As a natural result, 10 years later John de Bauer becomes a well-known American politologist, who has gone through deconstructive philosophy school. Apotheosis of his career is book "the Odyssey is Right" or "Deconstructive theory of Right" - the combination which is a priori impossible. It is proved by Debauer-junior's search for truth. He represents the post-war generation of children that judge by the mistakes of their fathers.

The moral relativism defines actions of Debauer-father and the contents of his popular book on rights, which, in fact, was written by him to justify his own impudence and deception, because intellectual honesty, in his opinion, is totally useless. Peter Debauer would go through many intellectual tests, but would not open up to his father when he found him, because he realized hidden from others moral inability of the modern German Odysseus.

In B. Shlink's poetics ideas of Thomas Mann are felt; when the latter wrote the tetralogy about Joseph, he created a concept of archetypical models of human behavior and thinking, which develop progressively throughout the history of human civilization. From the point of view of Jung, such mythological figures (or models) "are formulated results of the typical experience of the numerous variety of ancestors" [18, p. 317]. From Th. Mann's point of view, a human during evolution produces a mechanism of a free choice of right decisions and he has a genetically acquired "memory" to produce solely right actions, and he is able to repeat them and the realization of the necessity to improve his archetype contributes to his spiritual evolution [19, p. 427-433].

In the novel we can find reflections of the hero similar to those of Th. Mann. While creating a computer program to solve juridical issues, Peter Debauer consults a judge about principles of identification of typical judicature models. Deja vu turned out to be one of those principles. The victory of Napoleon under Austerliz is an example of déjà vu [20, p. 80].

In the novel "Homecoming" we have repeatedly faced with matrix models derived by the author. Thus, Johann Debauer's ex-classmate Gotthold Rank reminds a serene, becalmed Menelaus, returned from Troy to enjoy peace and prosperity.

Like Homer's character, Gotthold Rank tells his son a few interesting details on his father's personality; namely, about his eloquence talents, that attract and charm other people. Exactly this character gives Peter the crucial document to understand his father's personality - the copy of his school essay on the novel of Gottfried Keller "Dresses make people" with the theme "Venzel Strapinski - is a lier against his will?" that had been assessed by the teacher with a highest point. This essay is a key to 
open and, in fact, simple mechanism of life and success of the unpredictable personality of Johann Debauer, the sophisticated modern Ulysses. The main credo of Johann Debauer is a phrase from his school essay: "the issues of ethics could be neglected" [20, p. 321]. The way the document is given is also very interesting. The author shows it only in the end, when everything seems to be clear. The school essay of Johann Debauer brings into the communicative space of the novel another painful for German national consciousness problem: it is a theme of a German schoolteacher and his role in the formation of false moral values, which adds to allusions from the novels of Thomas and Heinrich Mann and so on. Revealing in the mythological images models of main psychological types and conflicts connected with the type of the personality, B. Shlink creates in his novel a number of Odysseuses, Penelopes and Telemaches. The Odysseus model manifests itself primarily in two main characters of the novel: Peter and Johann Debauers. However, the father personifies only destructive and immoral, which finally leads to his moral inability, the Odysseus-junior - Peter, who played Telemachus in the beginning of the novel, finds in his wanderings solid moral values. Having realized his mythological type, Peter Debauer does not "follow the trail", repeating his father's destiny. He would find his own home where there is his grandfather's desk and a chair - realia of the gone patriarchal idyll and the reminder on "Utility of Justice"; his Penelope - Barbary, and his Telemachus - Max, a teenager for whose fate he feels to be responsible. Perceiving the myth as a historical and dialectic process, B. Shlink, like Th. Mann, takes it as a peculiar cipher of the human experience, a model of development of the humanistic values, a prototype of mutual battle between progress and regress, which $\mathrm{b}$. Shlink masterfully describes in a communicative space of his novel.

\section{REFERENCES}

1. Hutcheon L. A Poetics of Postmodernism: History, Theory, Fiction. Routledge, 1988. Pp. 288.

2. Literary Theory: An Anthology. Wiley-Blackwell, 2010. Pp. 1336.

3. Nicol B. Postmodernism and the Contemporary Novel: A Reader. Edinburgh University Press, 2002. Pp. 496.

4. Gasparov B. M. Yazyk. Pamyat'. Obraz. Lingvistika yazykovogo sushchestvovaniya [Language. Memory. Image. Linguistics of Language Existence]. M., 1996.

5. Yukhnova I. S. Poetika dialoga i problemy obshcheniya v proze A. S. Pushkina i M. Yu. Lermontova: avtoref. ... dis. d-ra filol. nauk. Nizhnii Novgorod, 2012.

6. Yukhnova I. S. Obshchenie i dialog v tvorchestve A. S. Pushkina [Communication and Dialogue in the Works of A. S. Pushkin]. Saransk, 2014.

7. Yukhnova I. S. Problema obshcheniya i poetika dialoga v proze M. Yu. Lermontova [The Problem of Communication and Poetics of Dialogue in Prose of M. Yu. Lermontov]. Monografiya. Nizhnii Novgorod, 2011.

8. Kuchumova G. V. Roman v sisteme kul'turnykh paradigm (na materiale nemetskoyazychnogo romana 1980-2000 gg.): avtoref. dis. ... d-ra filol. nauk. Samara, 2010.

9. Frolov G. A. Filologiya i kul'tura. 2014. No. 2(36). Pp. 192-196.

10. Ovsyannikova Yu. O. Vestnik TvGu. Seriya «Filologiya». 2013. No. 6. Pp. 289-294.

11. Sharypina T. A. Vestnik Nizhegorodskogo universiteta. 2007. No. 2. Pp. 292-296.

12. Orr M. Intertextuality: Debates and Contexts. Polity, 2003. Pp. 256.

13. Allen Gr. Intertextuality (The New Critical Idiom). Routledge, 2000. Pp. 252.

14. Förster N. Die Wiederkehr des Erzählens. Deutschspachige Prosa der 80 er and 90 er Jahre. Berlin, 2001. 173 S.

15. Freund W. Der deutsche Roman der Gegenwart. München: Wilhelm Fink Verlag, 2001. 248 S.

16. Apinyan T. A. Igra v prostranstve ser'eznogo: igra, mif, ritual, son, iskusstvo i dr. [Game In the Space of Seriousness: Game, Myth, Ritual, Dream, Art, etc.]. Saint Petersburg, 2003.

17. Bakhtin M. M. Tvorchestvo Fransua Rable i narodnaya kul'tura srednevekov'ya i Renessansa [Art of Francois Rabelais and Popular Culture of the Middle Ages and Renaissance]. M., 1990.

18. Jung K. G. Psikhologicheskie tipy [Psychological Types]. Saint Petersburg, 1995.

19. Sharypina T. A. Modeli v sovremennoi nauke: edinstvo i mnogoobrazie. Kaliningrad: Izd-vo RGU, 2010. Pp. 427-433.

20. Schlinck B. Die Heimkehr. Zürich: Diogenes, 2006. 376 S. 
DOI: $10.15643 /$ libartrus-2015.1.1

\title{
Коммуникативное пространство и интертекстуальная подоснова в романе Б. Шлинка «Возвращение»
}

\author{
(C) Т. А. Шарыпина \\ Нижегородский государственный университет \\ Россия, 603950 г. Нижний Новгород, проспект Гагарина, 23. \\ Email: kafzl@yandex.ru
}

Рассматриваются своеобразие коммуникативного пространства в романе современного немецкого писателя Бернхарда Шлинка «Возвращение», включающее в себя литературный, исторический и социологический контекст, а также интертекстуальная подоснова романа, содержащая смысловые пласты по сути всех времён и народов; диалогические отношения, реализующиеся в стратегии общения героев произведения. Доказывается, что коммуникативное пространство не ограничиваются в романе античностью, но включает себя знаковые для немецкого менталитета произведения, мотивы, образы. В романе обыгрывается знаменитая дилемма Фауста Гёте между Словом и Делом. Открывая в мифологических образах модели основных психологических типов и основных конфликтов, связанных с тем или иным типом личности, Б. Шлинк выводит в романе целую галерею одиссеев, пенелоп и телемахов. Модель Одиссея прежде всего воплощается в двух главных героях романа: Петере и Иоганне Дебауерах. Однако если Иоганн воплощает в себе начало разрушительное и аморальное, что в конце концов приводит его к полной нравственной несостоятельности, то младший Одиссей - Петер, вначале игравший роль Телемаха, в своих странствиях находит прочные нравственные ориентиры. Воспринимая миф как исторический и диалектический процесс, Б. Шлинк, подобно Т. Манну, видит в нем своеобразный шифр человеческого опыта, своеобразную модель отработки человечеством гуманистических ценностей, прообраз взаимоборства прогрессивного начала и регресса, борьбу которых с такой виртуозной выразительностью демонстрирует нам Б. Шлинк на всём коммуникативном пространстве своего романа.

Ключевые слова: коммуникативное пространство, постмодернизм, интертекстуальность, диалог, роман, текст, архетипическая модель, речевое поведение.

Просьба ссылаться на эту работу как: Шарыпина Т. А. Коммуникативное пространство и интертекстуальная подоснова в романе Б. Шлинка «Возвращение» // Российский гуманитарный журнал. 2015. Т. 4. №1. С. 3-8.

\section{ЛИТЕРАТУРА}

1. Hutcheon L. A Poetics of Postmodernism: History, Theory, Fiction. Routledge, 1988. Pp. 288.

2. Literary Theory: An Anthology. Wiley-Blackwell, 2010. Pp. 1336.

3. Nicol B. Postmodernism and the Contemporary Novel: A Reader. Edinburgh University Press, 2002. Pp. 496.

4. Гаспаров Б. М. Язык. Память. Образ. Лингвистика языкового существования. М., 1996. 352 с.

5. Юхнова И. С. Поэтика диалога и проблемы общения в прозе А. С. Пушкина и М. Ю. Лермонтова: автореф.... дис. д-ра филол. наук. Нижний Новгород, 2012. 32 с.

6. Юхнова И. С. Общение и диалог в творчестве А. С. Пушкина. Саранск, 2014. 204 с.

7. Юхнова И. С. Проблема общения и поэтика диалога в прозе М. Ю. Лермонтова. Монография. Нижний Новгород, 2011. 219 c.

8. Кучумова Г. В. Роман в системе культурных парадигм (на материале немецкоязычного романа 1980 2000 г2.): автореф. дис. ... д-ра филол. наук. Самара, 2010. 47 с. 
9. Фролов Г. А. Немецкий роман на исходе литературного века: искушение реализмом // Филология и культура. 2014. №2(36). С. 192-196.

10. Овсянникова Ю. О. Гомеровский миф в романе Б. Шлинка «Возвращение» // Вестник ТвГу. Серия «Филология». 2013. Вып. 6. С. 289-294.

11. Шарыпина Т. А. «Мифический элемент» в драматургии объединенной Германии (Бото Штраус «Итака») // Вестник Нижегородского университета. 2007. №2. С. 292-296.

12. Orr M. Intertextuality: Debates and Contexts. Polity, 2003. Pp. 256.

13. Allen Gr. Intertextuality (The New Critical Idiom). Routledge, 2000. Pp. 252.

14. Förster N. Die Wiederkehr des Erzählens. Deutschspachige Prosa der 80 er and 90 er Jahre. Berlin, 2001. 173 S.

15. Freund W. "Neue Objektivität". Die Rück kehr zum Erzählen in den neunziger Janhren // Der deutsche Roman der Gegenwart. München: Wilhelm Fink Verlag, 2001. 248 S.

16. Апинян Т. А. Игра в пространстве серьёзного: игра, миф, ритуал, сон, искусство и др. СПб., 2003. 399 с.

17. Бахтин М. М. Творчество Франсуа Рабле и народная культура средневековья и Ренессанса. М., 1990. $543 \mathrm{c}$.

18. Юнг К. Г. Психологические типы. СПб., 1995. 716 с.

19. Шарыпина Т. А. Миф как смыслопорождающая модель в литературном сознании Германии второй половины ХХ века // Модели в современной науке: единство и многообразие. Калининград: Изд-во РГУ, 2010. C. 427-433.

20. Schlinck B. Die Heimkehr. Zürich: Diogenes, 2006. 376 S. 